Podstawowe idee i koncepcje w geografii, t. 9

Nowe i stare perspektywy oraz ujęcia w geografii na przełomie XX i XXI wieku

http://dx.doi.org/10.18778/8088-505-9.05

\author{
Danuta PIRóG \\ Instytut Geografii \\ Uniwersytet Pedagogiczny w Krakowie
}

\title{
STUDIA NA KIERUNKU GEOGRAFIA Z PERSPEKTYWY ABSOLWENTÓW WKRACZAJĄCYCH NA RYNEK PRACY PROPOZYCJA METODOLOGICZNA I WYNIKI BADAŃ
}

Zarys treści: $W$ dobie rosnących trudności tranzycji osób kończących uczelnie wyższe na rynek pracy, zasadne wydaje się sprawdzanie skuteczności przyjmowanych idei programowych i rozwiązań dydaktycznych, stosowanych na studiach, w zakresie pozyskiwania i utrzymania zatrudnienia przez młodzież kończącą kształcenie na kierunku geografia. Absolwenci są jednym z podstawowych podmiotów mogących dokonać oceny przydatności studiów w przejściu z etapu edukacji akademickiej do etapu zatrudnienia oraz sugerować konieczne zmiany w szeroko pojętej koncepcji kształcenia, które optymalizowałyby pozycję geografów na rynku pracy w przyszłości.

Celem opracowania jest analiza percepcji studiów na kierunku geografia z perspektywy pracujących i poszukujących zatrudnienia absolwentów; zaproponowanie i poddanie krytycznej ocenie zastosowania metody pól semantycznych do interpretacji wyników w badaniach jakościowych z zakresu geografii społecznej. Refleksje z przeprowadzonych badań są podstawą do namysłu nad możliwościami podnoszenia prestiżu geografii jako dyscypliny naukowej poprzez działania mające na celu zwiększanie szans pomyślnej tranzycji absolwentów.

Słowa kluczowe: absolwent; metoda pól semantycznych; program studiów; studia geograficzne; rynek pracy.

\section{WSTĘP}

Percepcja studiów na kierunku geografia, analizowana z perspektywy absolwentów, nie była w Polsce po roku 1989 przedmiotem pogłębionych i ogólnokrajowych badań naukowych, mimo że zainteresowanie młodzieży tymi studiami zmniejsza się systematycznie (Tracz, Hibszer 2013; Piróg 2014a). Ten niekorzystny trend, który nie tylko rodzi obawy o dalsze funkcjonowanie geografii jako akademickiego kierunku kształcenia, ale 
i osłabia jej pozycję jako nauki, powoduje że władze akademickich jednostek organizacyjnych dokładają wszelkich starań, aby pozyskać kolejnych kandydatów chcących studiować geografię. Konkurowanie o studenta przybiera rożne formy, począwszy od obniżania wymagań w procesie rekrutacji po często intuicyjne propozycje zmian programowych czy wprowadzanie nowych specjalności.

Jak wskazują badania prowadzone w innych krajach, jedną z najbardziej efektywnych strategii stabilizowania - na względnie zadowalającym poziomie - zainteresowania kandydatów studiowaniem na danym kierunku jest modernizowanie planu oraz programu studiów w nawiązaniu do opinii absolwentów, wyrażanych przez nich na ten temat z perspektywy ich sytuacji na rynku pracy. Absolwenci są jednym z podstawowych podmiotów, który może dokonać oceny przydatności studiów w przejściu $\mathrm{z}$ etapu edukacji akademickiej do etapu zatrudnienia oraz sugerować zmiany w szeroko pojętej koncepcji kształcenia, które optymalizowałyby ich pozycję na rynku pracy w przyszłości (Cranmer 2006; Nuñez, Livanos 2010). Akceptacja przez naukowców zasadności działań związanych z dostosowywaniem wizji i oferty edukacyjnej studiów geograficznych do zachodzących zmian na rynku pracy nie była i nadal nie jest jednak powszechna. Jak dowodzą studia literatury, przeciwnicy takich działań twierdzą, że spłycają one kształcenie uniwersyteckie, które powinno być skupione na wielostronnym rozwoju intelektualnym społeczeństwa, do swoistej edukacji zawodowej i tym samym zagrażają tradycyjnym wartościom akademickim (Piróg 2010b). Jednocześnie empirycznie ustalono, że kategoryczne odrzucanie zasadności projektowania studiów w nawiązaniu do zmian zachodzących na rynku pracy może spowodować wiele niekorzystnych konsekwencji, bezpośrednio dla absolwentów geografii, a pośrednio dla całej dyscypliny naukowej. Jedną z ważniejszych z nich jest niezadowalający wizerunek studiów geograficznych $\mathrm{w}$ społeczeństwie, propagowany przez rozczarowanych zawodowo absolwentów (Frazier 1994; Jonhston 1990; Gedye i in. 2004). Z kolei wysokie wskaźniki zatrudnialności są jednym z kluczowych czynników odpowiadających za liczbę osób chcących kształcić się na danym kierunku. Z tych względów wiele uczelni już wdrożyło lub jest $w$ trakcie tworzenia takich koncepcji programowych studiów geograficznych, które zapewniałyby absolwentom płynne wejście na rynek pracy. Proces ten odbywa się (choć najmniej dynamicznie) nawet na studiach doktoranckich (Solem i in. 2013).

W literaturze pojawiają się coraz częściej kategoryczne stanowiska zwolenników permanentnej adaptacji koncepcji studiów geograficznych do zmian społeczno-gospodarczych, polegające na przeciwstawianiu się ignorowaniu przez naukowców - geografów problematyki zatrudnialności, nazywając ten stan unikaniem odpowiedzialności, a nawet zaprzeczaniem idei badań geograficznych (Rooney i in. 2006). Ich zdaniem, geografia to ta dyscyplina naukowa, która jest predestynowana do badania szeroko ro- 
zumianych problemów współczesnego świata. Geografowie, zajmując się tymi zagadnieniami w kategoriach badawczych, nie mogą odcinać się od nurtu rynku pracy i bezrobocia czy czynić go interesującym kierunkiem analiz, a pomijać badaniami sytuację własnych absolwentów na tym rynku (Chalkley 1995).

Przyjmując argumenty obu grup przy jednoczesnej świadomości luki w zakresie badań dotyczących percepcji studiów na kierunku geografia przez absolwentów, celem , jaki stawiam sobie w niniejszym artykule:

a) Analiza percepcji studiów na kierunku geografia z perspektywy pracujących i poszukujących zatrudnienia absolwentów, poprzez rozpoznanie:

- oceny studiów geograficznych w zakresie ich przydatności do pozyskiwania i utrzymania pracy;

- sugestii zmian w szeroko pojętej koncepcji kształcenia.

b) Próba zastosowania nowej w geografii społecznej metody pól semantycznych do interpretacji wyników badań sondażowych, w których stosuje się pytania otwarte.

\section{ORGANIZACJA BADAŃ}

Do realizacji zadań zastosowano metodę sondażu diagnostycznego, który przeprowadzono w dwóch etapach: w okresie maj/czerwiec 2011 (I etap; badania ankietowe w formie papierowej) - styczeń/luty 2012 (II etap, ankieta online) ${ }^{1}$. Badania właściwe poprzedzono testowaniem narzędzi (na populacji 120 studentów geografii Uniwersytetu Pedagogicznego w Krakowie). Pierwszy etap adresowany był do osób kończących stacjonarne studia na kierunku geografia w roku akademickim 2010/2011 w czternastu uczelniach kształcących geografów. Pisemną zgodę na zrealizowanie takich badań uzyskano od władz dwunastu spośród czternastu uczelni. Celem tego etapu badań było m.in. poznanie percepcji i satysfakcji studentów z kształcenia się na kierunku geografia w kontekście poszukiwania pracy. W I etapie osobiście, z pomocą kierowników i pracowników naukowych danych jednostek, spotykano się ze studentami na każdej z uczelni na wcześniej ustalonych osobnych zebraniach lub cotygodniowych zajęciach kameralnych i wyjaśniając cele badań, proszono o udział w sondażu. Badanie miało charakter poufny, a nie anonimowy, gdyż na wypełnionym arkuszu respondenci byli proszeni o wpisanie swojego adresu mail. W ten sposób pozyskano ankiety od $1347^{2}$ osób, co stanowi około $78 \%$ wszystkich osób kończących studia stacjonarne na kierunku geografia w roku akademickim 2010/2011.

1 Badania sfinansowano ze środków budżetowych na naukę w latach 20102012 jako projekt badawczy nr N N114 076739.

$2 \mathrm{Na}$ podstawie kryterium rzetelności do dalszych analiz zakwalifikowano 1120 arkuszy. 
W II etapie badań, który odbył się około pół roku od momentu ukończenia studiów przez respondentów, rozesłano ankietę w wersji elektronicznej do wszystkich osób, które w pierwszym etapie zadeklarowały, iż po zakończeniu studiów planują niezwłocznie poszukiwać pracy. Wykonanie badania właśnie po około sześciu miesiącach od dnia formalnego zakończenia kształcenia podyktowane zostało ustaleniami, że ten okres najczęściej jest stosowany do poznania tempa i charakteru procesu przechodzenia z etapu edukacji do etapu pracy zawodowej (Müller, Gangl 2003). Takie plany wyraziło wówczas 597 badanych i do wszystkich tych osób skierowano elektroniczne zaproszenie do wzięcia udziału w sondażu (spersonalizowany link z hasłem indywidualnym, koniecznym do zalogowana $\mathrm{w}$ bazie). Celem tego etapu było zdiagnozowanie szeroko pojętej percepcji odbytych studiów geograficznych z perspektywy kilkumiesięcznych doświadczeń na rynku pracy oraz realnej sytuacji konkretnych absolwentów geografii na tym rynku, w nawiązaniu do ich wcześniejszych oczekiwań, planów.

Zebrany materiał statystyczny, zestawiony w dwóch bazach danych, posłużył do wygenerowania wynikowej bazy danych, która była relacyjnym połączeniem obu, gdzie podstawą relacji jeden-do-jednego był atrybut adresu mailowego, podawany w każdym z badań. Spersonalizowana zbiorowość 375 absolwentów stanowiła grupę badawczą do dalszych pogłębionych analiz statystycznych ilościowych i jakościowych. Populacja ta w dość równomierny sposób reprezentowała wszystkie stopnie studiów stacjonarnych, tworzyli ją bowiem absolwenci studiów I stopnia $(32,5 \%)$, drugiego stopnia $(32,0 \%)$ oraz studiów jednolitych magisterskich $(35,5 \%)$. W strukturze płciowej przeważały kobiety $(65,3 \%)$. Respondenci byli jednolici wiekowo - tworzyły ją osoby w wieku 22-24 lata (prawie 98\%).

Badani geografowie reprezentowali różne specjalności, tj. nauczycielskie (nauczanie geografii i innego przedmiotu), z zakresu ochrony środowiska, geografii fizycznej, gospodarki przestrzennej, turystyki, geografii społeczno-ekonomicznej, GIS oraz geografii regionalnej. Co siódmy absolwent nie był objęty kursami specjalizacyjnymi (dyplom z zakresu geografii ogólnej).

\section{NARZĘDZIA I METODY}

Arkusze ankietowe składały się z kilkunastu tematycznych grup pytań. Cel niniejszego opracowania sprawił, że skupiono się w nim w sposób szczególny na analizie wyników odpowiedzi na pytania, dotyczące estymacji przydatności studiów geograficznych w pozyskaniu zatrudnienia, sugestii ewentualnych korekt $w$ ich programie i planie, dokonywanych z punktu widzenia osób, które są w procesie przechodzenia na rynek pracy.

Ocenę przydatności studiów na rynku pracy, a w ich obrębie poszczególnych bloków kursów, które ukończyli indagowani, poznano przez zastosowa- 
nie pytań zamkniętych, skonstruowanych w wykorzystaniem 4-stopniowej skali (wcale, częściowo, w znacznej mierze, zdecydowanie).

Do zebrania opinii respondentów na temat ewentualnej modyfikacji studiów geograficznych zastosowano pytanie otwarte, które brzmiało: Jakie zmiany na kierunku geografia Pani/Pana zdaniem, przyczyniłyby się do zwiększenia szans absolwentów na rynku pracy? W tym miejscu trzeba zaznaczyć, że pytania otwarte nie są aktualnie często wykorzystywane $\mathrm{w}$ badaniach sondażowych, przede wszystkim z powodu trudności $\mathrm{w}$ analizowaniu, transponowaniu zebranego materiału na postać tabelaryczno-graficzną i interpretowaniu wyników. Odpowiedzenie na te pytania wymaga też dużego nakładu czasu i wysiłku ze strony respondentów, co niejednokrotnie zniechęca ich do rzetelnego wypełnienia kwestionariusza i w efekcie dostarcza badaczowi niepełnych danych do opracowania. Decyzję o wprowadzeniu pytania otwartego, przy pełnej świadomości utrudnień jakie niesie za sobą pozyskanie odpowiedzi i późniejsza analiza ich treści, podjęto z kilku powodów. Po pierwsze, zakresy informacji, które mogą być zakumulowane w odpowiedziach udzielanych na pytania otwarte, zdecydowanie zwiększają prawdopodobieństwo pogłębionego i wieloaspektowego rozpoznania tematu badawczego, rejestrują ważne informacje, które nie zostałyby - być może - uwzględnione przez osobę konstruującą kwestionariusz oraz nasycają i intensyfikują jakościowy charakter badań. Analiza prac z nurtów badawczych, nie tylko z zakresu procesu tranzycji, ale i kształcenia na różnych etapach edukacyjnych, dowodzi dynamicznego wzrostu zainteresowania badaniami jakościowymi, w tym badaniami z stosowaniem pytań otwartych (np.: Schomburg, Teichler 2006; Allen, Van der Velden 2007; Salas-Valasco 2007; Piróg 2010a). Po drugie, wybór tego pytania do zastosowania w nim formy otwartej wypowiedzi, wynikał z faktu, że indagowani byli absolwentami geografii na dwunastu różnych uczelniach. Różnice w koncepcji studiów w każdej jednostce czyniły niemożliwym skonstruowanie takiego pytania zamkniętego, który nie pominęłoby ważnych aspektów odnoszących się do badanego zagadnienia. Po trzecie w tym badaniu ważne było także zdiagnozowanie emocjonalnego stosunku respondentów do badanych problemów, który uzewnętrznia się m.in. w długości wypowiedzi, doborze sformułowań, określeń, stosowaniu wzmocnień (np. wykrzykników).

Podjęcie decyzji o zastosowaniu pytania otwartego w kluczowej, z punktu widzenia celów badawczych, kwestii zrodziło potrzebę poszukiwania metody umożliwiającej rzetelną i wieloaspektową analizę uzyskanych odpowiedzi. Studia metodologicznej literatury doprowadziły mnie do wyników badań francuskich specjalistów z zakresu leksyki, dotyczących metod poszukiwania interpretacji tekstu. Do tego celu wypracowali oni tzw. metodę pól semantycznych. Metoda ta osadzona jest na założeniu, iż „tekst nie jest przezroczysty. Szukanie znaczenia tekstu, zdania, wyrazu, oznacza przeanalizowanie wszystkich jego zastosowań i kontekstów, wyma- 
ga ciągłej pracy nad tekstem, pozornego rozłożenia ciagu wypowiedzeniowego i porządku wypowiedzi po to, by złożyć je na powrót zgodnie z czytelnościq znaczqcq" (Robin 1980, s. 252). Opracowanie tekstu/wypowiedzi polega na wyszukaniu słów-kluczy, a następnie skategoryzowaniu ich względem funkcji, które w nim pełnią, tj.:

- określeń (jaki jest podmiot, jakimi cechami się charakteryzuje, jaka jest jego istota, sposób bycia),

- asocjacji - powiązań pozytywnych syntagmatycznych i kontekstowych (z czym kojarzy się podmiot, z czym się wiąże, co mu towarzyszy), - opozycji - powiązań negatywnych (czemu przeciwstawiany jest podmiot; mogą być to na przykład opozycje formalne, oparte na przedrostkach ani, nie, anty; umotywowane morfologicznie, paralelne, np.: bogaty/biedny; specjalista/laik),

- ekwiwalentów - synonimów, które zastępują słowa klucze,

- opisu działań podmiotu (co robi podmiot, jak się zachowuje),

- opisu działań wobec podmiotu (jakie działania są podejmowane względem niego).

Cel i przedmiot badań podyktowały potrzebę częściowej modyfikacji klasycznej metody pól semantycznych, dokonania pewnych innowacji i adaptacji jej do specyfiki eksplorowanej problematyki. Działania te polegały na: wykorzystaniu części siatek relacji (określeń, asocjacji; opisu działań podmiotu i opisu działań wobec podmiotu) do analizy treści odpowiedzi udzielonych przez respondentów; dualnym kategoryzowaniu zarówno opisu działań podmiotu, jak i wobec podmiotu na rynku pracy (z rozróżnieniem na okres trwania studiów i po jego zakończeniu); wzbogaceniu analizy o emfatyczne znaki interpunkcyjne, jako dodatkowym (oprócz znaczeń wyrazów) sposobie rejestracji emocji (typu i nasilenia), które wydają się istotne w próbie holistycznej interpretacji treści (Piróg 2014c). Tak przepracowany materiał umożliwił wygenerowanie tabeli syntetycznej, która pozwoliła na dokonanie klasyfikacji i jakościowej charakterystyki sugerowanych przez respondentów zmian oraz ich emocjonalnego stosunku do tych zagadnień.

\section{WYNIKI}

\section{Przydatność w pozyskiwaniu pracy}

Respondenci krytycznie ocenili przydatność studiów geograficznych w pozyskaniu pracy. Tylko co dziesiąty pracujący geograf $(11,5 \%)$ stwierdził, że studia te $\mathrm{w}$ dużym stopniu były mu pomocne w znalezieniu pracy, a prawie co czwarty (23\%) uznał, że pomoc ta była częściowa. Pozostałe osoby prawie nie zauważyły korzyści na tym polu $(33,3 \%)$ lub zdecydowanie odrzucały pozytywny wpływ studiów geograficznych na pozyskanie zatrudnienia $(32,2 \%)$. 
Ciekawe są różnice w surowości oceny realnej (w przypadku pracujących) i prawdopodobnej (w przypadku niepracujących) przydatności kompetencji nabytych w toku różnych kursów. Najbardziej pesymistycznie aplikację tych kompetencji $\mathrm{w}$ pracy ocenili pracujący absolwenci, co w dużej mierze jest konsekwencją niskiego odsetka osób posiadających pracę w pełni lub częściowo związaną z ukończonym kierunkiem studiów. Należy podkreślić, że aż 61,0\% pracujących geografów wykonuje pracę zupełnie nie związaną z ukończonym kierunkiem (a nierzadko i z poziomem wykształcenia). Najwyższy sceptycyzm (odpowiedź wcale) odnotowano wobec umiejętności nabytych w bloku kursów kierunkowych, terenowych i podstawowych, w przypadku których ponad połowa pracujących absolwentów nie zauważała jakiegokolwiek ich przełożenia na pracę zawodową. Niepokoi także fakt, że blisko połowa $(44,8 \%)$ geografów nie dostrzega żadnego wykorzystania kapitału edukacyjnego, zgromadzonego w toku kursów specjalnościowych. Stosowanie dużej palety umiejętności wypracowanych na tych kursach w pracy zadeklarowało tylko 9,3\% badanych Najwyższy stopnień przydatności (odpowiedź zdecydowanie, $w$ znacznej mierze) przypisano blokowi kursów kształcących umiejętności interpersonalne, któremu co piąty pracujący przyznał taką ocenę oraz blokowi zajęć technologii informacyjnej, GIS i języków obcych, które co siódmy pracujący badany uznał za zadecydowanie lub w znacznej mierze potrzebne.

Tabela 1. Ocena przydatności kursów akademickich w pozyskaniu zatrudnienia

\begin{tabular}{|c|c|c|c|c|c|c|c|c|c|c|}
\hline \multirow{3}{*}{$\begin{array}{l}\text { W jakim stopniu } \\
\text { zajęcia przydają } \\
\text { się / mogą być } \\
\text { przydatne w pozy- } \\
\text { skaniu i wykony- } \\
\text { waniu pracy }\end{array}$} & \multicolumn{5}{|c|}{ Niepracujący } & \multicolumn{5}{|c|}{ Pracujący } \\
\hline & $\frac{0}{\sqrt[0]{0}}$ & 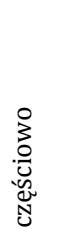 & 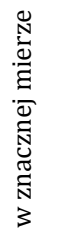 & 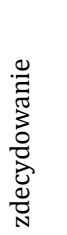 & 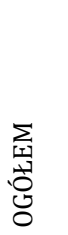 & $\begin{array}{l}\frac{0}{\widetilde{U}} \\
3\end{array}$ & 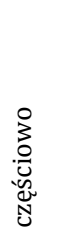 & 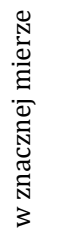 & 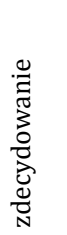 & 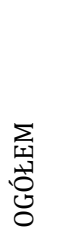 \\
\hline & \multicolumn{10}{|c|}{$\%$} \\
\hline $\begin{array}{l}\text { Blok przedmiotów } \\
\text { podstawowych }\end{array}$ & 24,2 & 61,6 & 12,1 & 2,1 & 100 & 51,4 & 33,9 & 11,5 & 3,3 & 100 \\
\hline $\begin{array}{l}\text { Blok przedmiotów } \\
\text { kierunkowych }\end{array}$ & 6,8 & 46,8 & 33,7 & 12,6 & 100 & 59,6 & 16,9 & 11,5 & 12,0 & 100 \\
\hline $\begin{array}{l}\text { Blok przedmiotów } \\
\text { w obrębie danej } \\
\text { specjalności }\end{array}$ & 4,2 & 23,2 & 42,1 & 30,5 & 100 & 44,8 & 30,1 & 15,8 & 9,3 & 100 \\
\hline $\begin{array}{l}\text { Blok zajęć informa- } \\
\text { tycznych GIS }\end{array}$ & 5,3 & 10,0 & 40,5 & 44,2 & 100 & 39,9 & 27,9 & 16,4 & 15,8 & 100 \\
\hline $\begin{array}{l}\text { Blok języków ob- } \\
\text { cych }\end{array}$ & 11,6 & 14,2 & 41,1 & 33,2 & 100 & 32,2 & 35,0 & 16,9 & 15,8 & 100 \\
\hline $\begin{array}{l}\text { Blok zajęć kształcą- } \\
\text { cych umiejętności } \\
\text { interpersonalne }\end{array}$ & 10,0 & 35,8 & 32,1 & 22,1 & 100 & 27,9 & 30,6 & 23,0 & 18,6 & 100 \\
\hline $\begin{array}{l}\text { Blok zajęć tereno- } \\
\text { wych }\end{array}$ & 12,1 & 44,2 & 28,4 & 15,3 & 100 & 58,5 & 19,7 & 12,0 & 9,8 & 100 \\
\hline
\end{tabular}

Źródło: opracowanie własne na podstawie badań ankietowych. 
Znacznie bardziej optymistycznie prawdopodobieństwo zastosowania umiejętności osiągniętych na tych grupach kursów postrzegały osoby nie pracujące, poszukujące pracy. Optymizm ten przejawia się po pierwsze tym, że generalnie ci absolwenci znaczniej rzadziej wybierali kategoryczną odpowiedź wcale, która tak wyraźnie dominowała pośród pracujących geografów. Po drugie mają oni nadzieję, że zwłaszcza dokonany przez nich wybór specjalności był, z punktu widzenia potrzeb rynku pracy, trafioną decyzją. Spodziewają się przynajmniej częściowej szansy stosowania wiedzy i umiejętności nabytych w toku studiów i aż $61 \%$ z nich oczekuje tego wobec kursów podstawowych, a blisko połowa także wobec kursów kierunkowych i zajęć terenowych (odpowiednio 46,8 i 44,2\%). Kompetencjami, które według ich prognoz, będą im zdecydowanie przydatne w pracy są te, które nabyli w bloku zajęć GIS $(44,2 \%)$, języków obcych $(33,2 \%)$ i kursach danej specjalności (30,5\%).

\section{Proponowane zmiany}

Stosując badanie pól semantycznych wyodrębniono następujące, proponowane przez absolwentów, główne obszary zmian studiów geograficznych:

- koncepcji studiów geograficznych,

- planu studiów (struktury i objętości poszczególnych kursów),

- programu studiów (strategii realizacji, metod, środków kształcenia).

Zanim nastąpi merytoryczna analiza zebranych wyników, należy zaznaczyć, że w wypowiedziach geografów zauważa się, m.in.:

- Zdecydowaną przewagę określeń i asocjacji o zabarwieniu pejoratywnym, często także ironicznym lub wyrażających swoistą litość (np.: absolwent geografii po studiach o takim programie to: ofiara własnych złudzeń, marzyciel, naiwniak, kolejny bezrobotny z „papierkiem”, idealista, „siłaczka”, nikt wyjątkowy, frajer jak każdy inny, zagubiony, kolejny sprzedawca w galerii handlowej) nad pozytywnymi (np.: człowiek dynamiczny, osoba, która wiele wie i potrafi się szybko przystosować);

- Bardziej emocjonalne (głównie negatywnie) nasycenie odpowiedzi pracujących geografów, znacznie chłodniejsze lub obojętne wypowiedzi osób pozostających bez pracy oraz wyraźną różnicę między osobami pracującymi i niepracującymi w jakości odpowiedzi. Absolwenci nie pracujący udzielali zdecydowanie bardziej rozległych, szczegółowych, bogatych $\mathrm{w}$ konkretne sugestie, odpowiedzi. Ich wypowiedzi były częściej nacechowane emocjami (stosowano wykrzykniki, pytajniki, słownictwo epitetowe). Refleksie respondentów pracujących były na ogół znacznie krótsze, chłodniejsze i wyzbyte otoczki emocjonalnej. Osoby pracujące, często $\mathrm{w}$ sposób przykry, zweryfikowały swoje poglądy $\mathrm{w}$ omawianym zakresie i dlatego $\mathrm{z}$ mniejszym zaangażowaniem (ilo- 
ściowym i jakościowym) podnosiły te kwestie. Nadto, paradoksalnie, charakter wypowiedzi osób pracujących był bardziej pesymistyczny niż ich nie pracujących rówieśników. Liczniejsze były także w tej grupie respondentów wypowiedzi, w których dawali wyraz przekonaniu, że los zawodowy geografów jest i będzie bardzo trudny, bez względu na ewentualne działania naprawcze.

Łącznie najwięcej wskazań i sugestii respondenci kierowali do planu studiów (276), kolejno do programu studiów (108), a na trzecim miejscu do koncepcji studiów (98). Generalnie, działania naprawcze, zalecane przez badanych, ogniskowały się wokół „zwiększania, zdecydowanego zwiększania, wydłużania, pogłębiania, poszerzania, rozbudowywania," i "modernizacji, unowocześnienia, poprawy, zmiany metod, zmiany proporcji”. W planie studiów najczęściej postulowano zwiększenie wymiaru zajęć i podnoszenie ich poziomu. Reformy w obrębie programu postrzegano zdecydowanie jako zmiany metod kształcenia, a w zakresie koncepcji studiów jako intensywniejszą ich specjalizację oraz wyższą jakość kształcenia.

\section{Koncepcja studiów geograficznych:}

Najczęściej wskazywanym obszarem zmian w koncepcji kształcenia była konieczność intensywniejszej specjalizacji studiów geograficznych (39 wypowiedzi), którą respondenci widzieli przede wszystkim jako dominację ilościową (liczba kursów, zakres godzinowy, ważność wyrażana tym, czy kurs kończy się egzaminem, czy zaliczeniem) kursów specjalnościowych nad kursami kierunkowymi i przedmiotowymi. Oprócz tego oczekiwali rozbudowy zajęć z danej specjalności i specjalizowania się już od pierwszego roku studiów (obecnie przeważa model wyboru specjalności od drugiego roku studiów) na przykład pisząc: „więcej zajęć z konkretnej specjalizacji, bo rynek pracy wymaga specjalistycznych umiejętności a nie wiedzy ogólnej" (fragment wypowiedzi, absolwent niepracujący). Absolwenci uważali, że ich start na rynku pracy byłby łatwiejszy, gdyby mogli specjalizować się w dwóch zakresach jednocześnie, wybierać specjalności z jeszcze szerszej palety ofertowej oraz gdyby specjalności te były skorelowane wyraźnie z potrzebami rynku pracy (tak twierdzą pracujący) lub ich nazewnictwo było atrakcyjne, „dobrze brzmiało”: „potrzebna jest zmiana nazw specjalizacji, hasła musza być nośne, dzisiejsze społeczeństwo, które geografię rozumie tylko jako przedmiot $w$ szkole, nie wie co to jest paleogeomorfologia a tym bardziej dostrzec szansę, że osoba z takq specjalnościq ma jakiekolwiek przydatne współczesnemu człowiekowi umiejętności" (fragment wypowiedzi - absolwent niepracujący).

Takiego trendu zmian w kierunku intensyfikacji specjalizacyjnej zdecydowanie częściej (blisko czterokrotnie częściej) domagali się absolwenci niepracujący. Osoby pracujące nie majoryzowały specjalizacji jako klucza powodzenia geografów na rynku pracy. 
Kolejno wskazywanym ważnym obszarem zmian było zapewnianie wyższej jakości kształcenia na studiach geograficznych (30 wypowiedzi), które absolwenci rozumieli głównie jako zmiany w formach realizacji zajęć, tj. w godzinowej przewadze zajęć w formie ćwiczeń nad wykładami, zwiększeniu liczby godzin zajęć $\mathrm{w}$ ogóle, proponowaniu bogatszej puli kursów do wyboru indywidulanego przez studenta, wzmożoną internacjonalizację zajęć (obligatoryjne kursy w językach obcych, poza lektoratem). Respondenci dostrzegali także szkodliwość praktyk rozluźniania kryteriów rekrutacyjnych i przyjmowania na studia dużej populacji chętnych. Potrzebę zaostrzenia kryteriów naboru argumentowali najczęściej bardzo dużą nadwyżką osób z dyplomem studiów geograficznych i przyjmowaniem na studia młodzieży o niewystarczającym potencjale intelektualnym. Skutkiem takich praktyk, zdaniem badanych, jest wchodzenie na rynek pracy osób o zdecydowanie słabiej wykształconych kompetencjach, które $\mathrm{w}$ ten sposób pogłębiają i tak już niezbyt idealny wizerunek geografii i absolwentów kierunku geografia.

Indagowani niepracujący czterokrotnie częściej niż posiadający pracę wyraźnie podkreślali zasadność włączania w kreowanie i realizację procesu kształcenia geograficznego interesariuszy zewnętrznych, pracodawców. Ich zdaniem, pracodawcy powinni mieć realny wpływ na program studiów i prowadzić część kursów $w$ ich toku. Idea ta jest już realizowana w wielu uczelniach, ale albo skutki współpracy są jeszcze niewidoczne, skromne, albo nie oznajmiane studentom.

Z kolei osoby zatrudnione wskazywały potrzebę nowego typu zajęć, które - ich zdaniem - powinny stać się elementem oferty dydaktycznej studiów geograficznych, a które to kursy są tak zwanymi praktycznymi kursami z zakresu poruszania się na rynku pracy (wśród geografów szukających pracy nie odnotowano żadnej sugestii w tym zakresie). Absolwenci wyrażają potrzebę uzupełnienia tej luki, na przykład słowami: "gro z nas nie wie kompletnie jak odnaleźć się na rynku pracy" (absolwent pracujący).

\section{Plan i program studiów:}

W swoich wypowiedziach dotyczących zakresu zmian na studiach geograficznych, respondenci dali najwięcej wskazówek (276) na temat planu studiów. Analiza semantyczna doprowadziła do zgrupowania ich w sugestie odnoszące się przede wszystkim do zwiększenia wymiaru zajęć już funkcjonujących (130 wypowiedzi), podnoszenia poziomu zajęć (49), wprowadzenia nowych kursów (48) oraz umocnienia ogniwa praktyk zawodowych (35). Redukcję bądź eliminację kursów wskazywano stosunkowo rzadko (łącznie 14 wypowiedzi). Geografowie czuli niedosyt ilościowy wielu kursów i dlatego widzieli potrzebę zwiększenia liczby godzin, przede wszystkich z zajęć GIS, lektoratu języka obcego, teledetekcji, planowania przestrzennego, analizy przestrzennej, statystyki, komunikacji interpersonalnej, matematyki. Konieczność podniesienia jakości kursów 
wymieniano wobec GIS i języków obcych, przy czym w pierwszym przypadku młodzież oczekiwała poznania „profesjonalnych programów, narzędzi, wykorzystywanych $w$ realiach", a często otrzymywała „wprowadzenie do GIS, podstawy, równanie zadań do moźliwości osób najsłabszych w grupie, a przecież to sq studia, nie szkółka!". W zakresie języków obcych geografowie czuli niedosyt w nabywaniu praktycznej umiejętności komunikacji zamiast „kolejnego powtarzania gramatycznych zasad budowy zdań $w$ poszczególnych czasach”, poznawania specjalistycznego języka, a nie „przerabiania czytanek tematycznych o wakacjach, sportach, częściach ciała itp., jak dla małych dzieci".

Nadto, absolwenci uważali, że niezbędne jest wprowadzenie nowych kursów w obrębie ich specjalności. Najczęściej wymieniali kursy polegające na nauce praktycznych/zawodowych umiejętności, np.: praktyczna organizacja pracy w biurze, obsługa programów rezerwacyjnych (specjalności turystyczne), pisania projektów unijnych z zakresu ochrony środowiska, projektowania stron internetowych.

Bardzo dużą szansę na poprawę swojej sytuacji na rynku pracy upatrują w praktykach zawodowych. Uważają za pilne zwiększenie wymiaru godzinowego praktyk zawodowych, zapewnienie studentom możliwości odbywania praktyk w potencjalnych miejscach pracy. Osoby pracujące częściej wskazywały jako konieczne realizowanie długich (półrocznych) staży.

Część zmian, które za potrzebne uważają geografowie posiadający pracę, różni się od tych, które za pożądane wskazują osoby niepracujące. Ci pierwsi niemal dwukrotnie częściej sugerowali zasadność wprowadzenia nowych kursów, które dałyby studentom szansę wykształcenia dodatkowych umiejętności (głównie transferowalnych). Drudzy preferowali (też prawie dwukrotnie częściej) zwiększenie wymiaru zajęć. To zainteresowanie osób zatrudnionych uzupełnieniem programu studiów o nowe kursy prawdopodobnie jest rezultatem doświadczenia nabytego przez nich w procesie poszukiwania i wykonywania pracy, które ujawniło nie tyle niedobory kompetencji przedmiotowych, ile brak innych umiejętności, potencjalnie do opanowania na nowych zajęciach. Ci, którzy jeszcze nie znaleźli pracy, czuli, że zakres kompetencji wykształcanych na kierunku geografia jest wystarczający, ale ich jakość nie zawsze jest na najwyższym poziomie, stąd ich nadzieja, że dodatkowe zajęcia byłyby szansą na optymalizację $w$ tym zakresie.

Wiele sformułowań w wypowiedziach absolwentów (108 wskazówek) ogniskowało się wokół realizacji programu studiów, w tym zwłaszcza dotyczyło propozycji zmian metod kształcenia (69), środków dydaktycznych (27) oraz zakresu treści (12).

Bezwzględnie wszyscy absolwenci podkreślali pilną potrzebę reorientacji metod kształcenia (z podających na praktyczne). Opinie te wyrażano z dużym ładunkiem emocjonalnym, a najczęściej powtarzały się wypowiedzi, typu: „więcej zajęć, na których praktycznie uczymy się czegos", , więcej 
praktyki, mniej teorii"; wykonywanie prac przez studentów, a nie patrzenie, jak to robi pracownik”, ,praktyczne zdobywanie wiedzy, a nie wkuwanie ze skryptu”, „więcej myślenia, działania, mniej encyklopedyzmu”.

Warte pogłębionej refleksji jest wymienienie, ale przez skromną grupę geografów (11 osób niepracujących; ale tylko dwie pracujące) potrzeby częstszej pracy $\mathrm{w}$ terenie i ćwiczeń terenowych. To marginesowe potraktowanie prac terenowych, które są postrzegane jako istota badań i studiów geograficznych, jest zaskakujące, niepokojące i rodzi pytanie o przyczyny takiego stanu.

Badani, z dużym zaangażowaniem emocjonalnym, podkreślali potrzebę samodzielnej pracy studenta z wykorzystaniem nowoczesnych środków dydaktycznych, zwłaszcza sprzętu pomiarowego, laboratoryjnego, pomocy dydaktycznych, oprogramowania. Wyrażali to pisząc najczęściej podobnie do cytowanych dwóch wypowiedzi "powinniśmy korzystać z nowoczesnego sprzętu, a nie z okazów muzealnych", "niezbędne jest wykorzystywanie na ćwiczeniach nowoczesnych przyrządów i nie tylko ich pokazanie, ale używanie" (Piróg 2014b).

W sugestiach optymalizacji kształcenia na kierunku geografia, tylko czterokrotnie poruszono bezpośrednio aspekt kadry akademickiej, twierdząc, że powinno nastąpić odmłodzenie w strukturze wiekowej nauczycieli akademickich oraz że od tych, którzy prowadzą kursy zawodowe, należałoby koniecznie wymagać doświadczenia zawodowego.

\section{PODSUMOWANIE}

Przeprowadzone badania dowodzą, że absolwenci dość surowo oceniają przydatność dyplomu ukończenia studiów na kierunku geografia i aktualnej koncepcji kształcenia w pozyskaniu pracy. Wszyscy wyraźnie optowali za podnoszeniem jakości procesu edukacyjnego, zwiększeniem wymiaru części zajęć, majoryzacją praktycznych metod kształcenia. Osoby pracujące zdecydowanie wyżej ceniły wzbogacenie programu o nowe kursy i praktyki zawodowe. Młodzież niepracująca z kolei upatrywała szans zwiększenia konkurencyjności geografów w jeszcze większej specjalizacji, zmianach metod i środków dydaktycznych. Osoby niepracujące wydają się bardziej wierzyć $\mathrm{w}$ przydatność studiów $\mathrm{w}$ procesie wejścia na rynek pracy niż te, które są zatrudnione. Pracujący częściej też nie udzielali konstruktywnej odpowiedzi, ale twierdząc m.in., że „nie ma miejsc pracy dla geografów”, „zmiany w programie - raczej złudne działanie - rynek nie potrzebuje tylu geografów", "jest małe zapotrzebowanie na geografów, nic tu nie pomoże", ujawniali swoje rozczarowanie i rezygnację.

Wart podkreślenia jest fakt, że tylko pojedyncze osoby chciały uszczuplać program studiów i tym samym zmniejszać sobie zakres obowiązków. Jest to cenna informacja, która powinna uczelnie ośmielać w stawianiu wysokich wymagań i wzbogacaniu programów studiów. 
Analiza semantyczna treści odpowiedzi absolwentów wyraźnie uwidacznia także i to, że nie zawsze czują się oni korzystnie postrzegani przez pracodawców, którzy słysząc, iż mają do czynienia z osobami, które ukończyły studia geograficzne, nie osadzali ich $\mathrm{w}$ ramach określonego wizerunku profesjonalnego specjalisty o sprecyzowanym pakiecie umiejętności.

Przeprowadzone badania wydają się - po raz kolejny - zachęcać do namysłu nad możliwościami podnoszenia prestiżu geografii jako dyscypliny naukowej, tym razem poprzez działania mające na celu zwiększanie szans pomyślnej tranzycji absolwentów.

Wydaje się, że błędem byłby całkowity opór i brak reakcji wobec sugestii zmian zgłaszanych przez absolwentów w zakresie modernizacji koncepcji studiów. Jednocześnie w czasach, kiedy jedyną stałą cechą rynku pracy jest jego zmienność, niewiele kierunków kształcenia akademickiego może poprzestać na przygotowywaniu do wykonywania jasno sprecyzowanego zawodu (Croot, Gedye 2006). Istnieje zatem zwiększone zapotrzebowanie na takie koncepcje studiów geograficznych, by promowały one specjalistów gotowych holistycznie rozwiązać problemy środowiskowe i przestrzenne, współpracować z przedstawicielami wielu innych dyscyplin i tą drogą promować absolwentów jako kompetentnych praktyków o szerokich horyzontach i bogatej palecie kompetencji. Za niezbędny element lepszego przygotowania studentów geografii do pozyskania atrakcyjnej pracy uznano także zachęcanie nauczycieli akademickich do dokształcania metodycznego, a kierowników jednostek do organizowania tego typu warsztatów dla swoich pracowników. Niełatwa sytuacja geografii w Polsce wydaje się jednoznacznie sugerować potrzebę dołożenia wyjątkowej dbałości o to, by ukończenie tego kierunku studiów umożliwiało absolwentom jak najlepszy start zawodowy, a przez to kreowało pożądany wizerunek geografii jako tej dyscypliny, która jest zarówno doskonałą drogą do rozwoju intelektualnego, zaspokajania zainteresowań oraz pasji badawczych, jak i do pozyskania satysfakcjonującej pracy.

\section{LITERATURA}

Allen J., Van der Velden R., 2007, Transition from higher education to work, [w:] U. Teichler (ed.), Careers of university graduates: Views and experiences in comparative perspectives, Dordrecht: Springer, s. 55-78.

Chalkley B., 1995, Geography staff placements: nice work? „Journal of Geography in Higher Education", 19(2), s. 234-239.

Cranmer S., 2006, Enhancing graduate employability: best intentions and mixed outcomes, „Studies in Higher Education”, 31(2), s. 169-184.

Croot D., Gedye S., 2006, Getting the Most out of Progress Files and Personal Development Planning, ,Journal of Geography in Higher Education”, 30(1), s. 173-179. 
Frazier J. W., 1994, Geography in the workplace: a personal assessment with a look to the future, „Journal of Geography”, 93(1), s. 29-35.

Gedye S., Fender E., Chalkley B., 2004, Students' Undergraduate Expectations and Postgraduation Experiences of the Value of a Degree, „Journal of Geography in Higher Education", 28(3), s. 381-396.

Johnston R. J., 1990, Exploring graduate dissatisfaction with British geography degree courses, „Journal of Geography in Higher Education”, 14(1), s. 39-53.

Müller W., Gangl M., 2003, The transition from school to work: a European perspective, [w:] W. Müller, M. Gangl (eds.), Transitions from education to work in Europe, Oxford University Press, Oxford, s. 1-22.

Nuñez I., Livanos I., 2010, Higher education and unemployment in Europe: an analysis of the academic subject and national effects. „Higher Education”, 59, s. 475-487.

Piróg D., 2010a, Sondaż diagnostyczny w badaniach z zakresu dydaktyki geografii - wybrane determinanty responsywności, [w:] S. Liszewski (red.), Obszary metropolitarne we współczesnym środowisku geograficznym, Łódź, Wydawnictwo UŁ, s. 415-425.

Piróg D., 2010b, Studia wyższe a rynek pracy w Polsce - zarys stanu badań, [w:] B. Sitarska, K. Jankowski, R. Droba (red.), Studia wyższe z perspektywy rynku pracy, Siedlce, Wyd. Akademii Podlaskiej, s. 61-80.

Piróg D., 2014a, Destinations of geography graduates on the labour market in Poland and other countries, „Geographia Polonica”, 87(1), s. 95-112.

Piróg D., 2014b, Do geography studies facilitate a smooth transition to the job market? Reflections of working and jobseeking graduates „Journal of Geography in Higher Education", 38(2), s. 155-174.

Piróg D., 2014c, W poszukiwaniu metodologicznych innowacji w badaniach jakościowych przykład z analiz przechodzenia absolwentów geografii na rynek pracy, „Annales Universitatis Paedagogicae Cracoviensis Studia Geographica", VI, 162, s. 9-19.

Robin R., 1980, Badanie pól semantycznych: doświadczenia Ośrodka Leksykologii Politycznej w Saint-Cloud, [w:] M. Głowiński (red.), Język i społeczeństwo, Warszawa, Czytelnik, s. 205-282.

Rooney P., Kneale P., Gambini B., Keiffer A., Vandrasek B., Gedye S., 2006, Variations in International Understandings of Employability for Geography, "Journal of Geography in Higher Education", 30(1), s. 133-145.

Salas-Valasco M., 2007, The transition from higher education to employment in Europe: the analysis of time to obtain the first job, „Higher Education”, 54(3), s. 333-360.

Schomburg H., Teichler U. (red.), 2006, Higher education and graduate employment in Europe. Results from graduate surveys from twelve countries, „Higher Education Dynamics”, 15 , Springer.

Solem M., Kollasch A., Lee J., 2013, Career goals, pathways and competencies of geography graduate students in the USA, ,Journal of Geography in Higher Education”, 37(1), s. 92-116.

Tracz M., Hibszer A., 2013, Geography studies in Poland after 1989 - selected issues, „Miscellanea Geographica - Regional Studies on Development", 17(3), s. 19-25. 


\section{Geography study programmes from the standpoint of graduates entering the labour market: a methodological proposal and research findings}

Summary: In the time when university graduates are experiencing growing difficulties in their transition into the labour market, it seems relevant to verify the effectiveness of curriculum concepts and teaching solutions, as adopted in university programmes, in ensuring geography graduates' employability, understood as their ability both to find and to retain a job. Graduates are essentially in a position to assess how useful their university experience has been in ensuring their transition from education to employment and to suggest necessary changes to be made to the education approach, in its broad sense, in order to optimise geographers' labour market position in the future.

This study aims at: analysing the perception of geography study programmes by working and job-seeking graduates; suggesting, and making a critical assessment of, the use of semantic fields method for interpreting results in qualitative research in social geography. The analysis of the research is the basis for further reflection on the possibility of raising the profile of geography as an academic discipline through action aiming at enhancing the prospects of graduates' successful transition.

Keywords: curriculum; geography study programmes; graduate; labour market; semantic fields method. 